\title{
ОСОБЛИВОСТІ РЕАЛІЗАЦІЇ ФУНКЦІЙ ПРОКУРАТУРИ НА РЕГІОНАЛЬНОМУ РІВНІ: АДМІНІСТРАТИВНО-ПРАВОВИЙ АСПЕКТ
}

Вступ. Відповідно до Конституції України прокуратура становить єдину систему, яка в порядку, передбаченому законом, здійснює встановлені Основним законом функції з метою захисту прав і свобод людини, загальних інтересів суспільства та держави. Більшою мірою поняття прокуратури розкривається через функції, визначені в Конституції та Законі України «Про прокуратуру». Враховуючи напрями діяльності, прокуратура є правоохоронним органом, до виключної компетенції якого зараховано підтримання публічного обвинувачення в суді; організацію i процесуальне керівництво досудовим розслідуванням, вирішення відповідно до закону інших питань під час кримінального провадження, нагляд за негласними та іншими слідчими і розшуковими діями органів правопорядку; представництво інтересів держави в суді у виключних випадках і в порядку, що визначені законом. Сучасний стан організації та діяльності органів прокуратури потребує удосконалення, про що свідчить низький рівень довіри громадян до органів прокуратури загалом та об'єктивні потреби реформування регіональних прокуратур, створення якісно нової моделі організації та діяльності прокуратури 3 використанням найкращого міжнародного досвіду та здобутків доктрини адміністративного права.

Вирішення зазначених питань має відбуватися за результатами грунтовних доктринальних досліджень адмі- ністративно-правових засад організації та діяльності прокуратури загалом та особливостей реалізації функцій прокуратури на регіональному рівні. Вказані дослідження мають створити теоретико-методологічну основу для удосконалення правового регулювання організації та діяльності прокуратури на регіональному рівні, визначити основні принципи такого удосконалення та сформувати фундаментальну концепцію нової моделі організації та діяльності регіональної прокуратури.

Методологія цього дослідження спирається на органічне поєднання філософських, загальнонаукових та спеціально-юридичних методів дослідження, серед яких ключову роль відіграють закони філософського методу діалектики (єдності та боротьби протилежностей, переходу кількісних змін у якісні), а також прийом «заперечення заперечення». Серед загальнонаукових методів дослідження застосовуються прийоми логічного методу (аналіз, синтез, дедукція та індукція), системний та структурно-функціональний методи, прийоми соціологічного методу тощо. Із спеціально-юридичних методів дослідження використовуються методи юридичної логіки та юридичної статистики, метод юридичної догматики (як різновид аксіоматичного методу) та метод юридичного моделювання.

Питання адміністративно-правового забезпечення діяльності право- 
охоронних органів досліджуються в роботах фахівців у сфері адміністративного права, серед яких роботи О. Бандурки, В. Бевзенка, М. Віхляєва, Н. Губерськой, С. Гусарова, Р. Калюжного, Т. Коломоєць, В. Колпакова, А. Комзюка, О. Кузьменко, В. Курила, Д. Лук'янця, Д. Лученка, П. Лютікова, Р. Мельника, О. Миколенка, Н. Нижник, Д. Приймаченка, Ю. Севрука, С. Стеценка, М. Тищенка, А. Школика та інших вчених-адміністративістів.

Актуальні питання адміністративно-правового забезпечення організації та діяльності органів прокуратури досліджували в своїх працях такі відомі науковці, як О. Агєєв, М. Івчук, О. Іщук, С. Кулинич, В. Миколенко , Є. Попович, В. Сухонос, В. Шуба, М. Якимчук та інші.

3 останніх досліджень варто згадати роботи Ю. Чаплинської «Адміністративно-правове забезпечення реформування органів прокуратури України» [1], П. Шаганенко «Адміністративно-правове регулювання організаційного забезпечення діяльності органів прокуратури» [2], С. Циганка «Поняття і зміст адміністративноправового забезпечення діяльності прокуратури України» [3], О. Баганця «Адміністративно-правове забезпечення реформи органів прокуратури України» [4], В. Карпунцова «Процесуальна компетенція органів прокуратури України: адміністративно-правовий аспект» [5]. Проте особливості реалізації функцій прокуратури на регіональному рівні ще не були предметом окремого дослідження, що актуалізує необхідність доктринального аналізу зазначеної теми.

Постановка завдання. Метою наукової публікації $€$ дослідження особливостей реалізації функцій прокуратури на регіональному рівні в контексті рівня їх адміністративно-правового забезпечення.

Результати дослідження. Адміністративно-правове забезпечення організації та діяльності регіональних про- куратур здійснюється за допомогою нормативної основи, яку становлять чинні закони та підзаконні нормативно-правові акти. Основним правовим засобом забезпечення реалізації окремих функції прокуратури є накази Генерального прокурора, якими детально регламентується порядок діяльності прокурорів, їх взаємодія 3 органами прокуратури вищого рівня, іншими правоохоронними органами тощо. Остання реформа органів прокуратури регламентована Законом України «Про внесення змін до деяких законодавчих актів України щодо першочергових заходів із реформи органів прокуратури» від 19 вересня 2019 р. [6].

Конституція України містить вичерпний перелік функцій прокуратури: підтримання публічного обвинувачення в суді; організація i процесуальне керівництво досудовим розслідуванням, вирішення відповідно до закону інших питань під час кримінального провадження, нагляд за негласними та іншими слідчими і розшуковими діями органів правопорядку; представництво інтересів держави в суді у виключних випадках і в порядку, що визначені законом [7].

Відповідно до ст. 2 Закону України «Про прокуратуру» на прокуратуру покладаються такі функціі: підтримання державного обвинувачення в суді; представництво інтересів громадянина або держави в суді у випадках, визначених цим Законом та главою 12 розділу III Цивільного процесуального кодексу України; нагляд за додержанням законів органами, що провадять оперативно-розшукову діяльність, дізнання, досудове слідство; нагляд за додержанням законів при виконанні судових рішень у кримінальних справах, а також при застосуванні інших заходів примусового характеру, пов'язаних з обмеженням особистої свободи громадян.

У ч. 3 ст. 3 Закону України «Про прокуратуру» прямо визначено, що на прокуратуру не можуть покладатися функції, не передбачені Консти- 
туцією України [8]. Отже, нагляд за додержанням законів у процесі виконання судових рішень у кримінальних справах, а також застосування інших заходів примусового характеру, пов'язаних з обмеженням особистої свободи громадян, органи прокуратури здійснюють до утворення відповідних органів нагляду Кримінально-виконавчої служби України (до набрання чинності законом про створення подвійної системи регулярних пенітенціарних інспекцій).

Порядок реалізації функції підтримання публічного обвинувачення в суді регламентовано Кримінальним процесуальним кодексом України. Крім того, реалізація цієї функції частково регламентована в розділі $\mathrm{V}$ «Організація діяльності прокурорів у судовому провадженні» наказу Генеральної прокуратури України № 51 від 28 березня 2019 р. «Про затвердження Порядку організації діяльності прокурорів і слідчих органів прокуратури у кримінальному провадженні» [9].

Згідно з п. 3 розділу $\mathrm{V}$ зазначеного наказу участь у судовому провадженні в суді апеляційної інстанції з перегляду судових рішень беруть:

- прокурор у провадженні (група прокурорів), керівник органу прокуратури вищого рівня, який подав апеляційну скаргу, в разі наявності позиції щодо ї особистої участі в апеляційному розгляді;

- прокурори структурних підрозділів регіональних прокуратур у разі наявності позиції щодо участі в апеляційному розгляді чи делегування таких повноважень;

- прокурори структурних підрозділів підтримання обвинувачення в суді прокуратур регіонального рівня у кримінальних провадженнях за скаргами на судові рішення, ухвалені за участю прокурорів місцевих прокуратур [9].

Прокурори, які беруть участь в апеляційному провадженні, під час виконання своїх повноважень відповідно до вимог законодавства: висловлюють мотивовану позицію щодо законності оскарженого судового рішення в межах вимог, викладених в апеляційних скаргах, а за наявності підстав для прийняття рішення на користь осіб, в інтересах яких апеляційні скарги не надійшли, ініціюють прийняття судом відповідного рішення; ініціюють повторне дослідження обставин кримінального провадження за умови, що вони досліджені судом першої інстанції неповністю або з порушеннями, а також ставлять питання про дослідження доказів, клопотання про дослідження яких судом першої інстанції відхилені або про які стало відомо після ухвалення судового рішення; здійснюють інші повноваження, передбачені КПК України [9].

3 огляду на важливість реалізації функції прокуратури України щодо підтримання публічного обвинувачення в суді, існує об'єктивна необхідність розробки окремого наказу Генерального прокурора, який буде детально регламентувати реалізацію зазначеної функції. У перспективному наказі доцільно регламентувати не тільки обов'язкові елементи та стадії реалізації функції підтримання публічного обвинувачення в суді, але й розмістити рекомендації щодо тактики та методики виконання прокурором окремих процесуальних дій - проголошення вступної промови, визначення обсягу доказів, що підлягають дослідженню, та порядку їх дослідження, допиту обвинуваченого, потерпілого та свідків, участі у судових дебатах тощо. У вказаних рекомендаціях доцільно врахувати останні напрацювання науковців у сфері кримінального процесу, а також правові позиції (висновки) Верховного Суду (постанови Касаційного кримінального суду у складі Верховного Суду та Великої Палати Верховного Суду).

Однією з основних функцій прокуратури є функція організації і процесуального керівництва досудовим розслідуванням. Правовою основою 
для адміністративно-правового забезпечення реалізації цієї функції є КПК України, Закон України «Про організаційно-правові основи боротьби 3 організованою злочинністю» тощо. Так, відповідно до ч. 2 ст. 36 КПК України, прокурор, здійснюючи нагляд за додержанням законів під час проведення досудового розслідування у формі процесуального керівництва досудовим розслідуванням, уповноважений: доручати слідчому, органу досудового розслідування проведення у встановлений прокурором строк слідчих (розшукових) дій, негласних слідчих (розшукових) дій, інших процесуальних дій або давати вказівки щодо їх проведення чи брати участь у них, а в необхідних випадках особисто проводити слідчі (розшукові) та процесуальні дії в порядку, визначеному цим Кодексом; доручати проведення слідчих (розшукових) дій та негласних слідчих (розшукових) дій відповідним оперативним підрозділам; скасовувати незаконні та необгрунтовані постанови слідчих; ініціювати перед керівником органу досудового розслідування питання про відсторонення слідчого від проведення досудового розслідування та призначення іншого слідчого за наявності підстав, передбачених цим Кодексом, для його відводу, або у разі неефективного досудового розслідування [10].

Безпосереднім адміністративноправовим засобом забезпечення реалізації вказаної функції $€$ Наказ Генеральної прокуратури № 51 від 28 березня 2019 року «Про затвердження Порядку організації діяльності прокурорів і слідчих органів прокуратури у кримінальному провадженні» [9].

Так, відповідно до п. 5 розділу I «Загальні положення» зазначеного наказу керівники прокуратур регіонального рівня, їх перші заступники та заступники відповідно до розподілу обов'язків забезпечують ефективну взаємодію у кримінальному провадженні регіональних, військо- вих та місцевих прокуратур, розташованих у межах однієї адміністративно-територіальної одиниці, за необхідності створюють за погодженням із Генеральною прокуратурою України міжрегіональні групи прокурорів або слідчих прокуратури [9].

Згідно з п. 2 розділу IV «Організація діяльності прокурорів під час проведення досудового розслідування» Наказу Генеральної прокуратури № 51 від 28 березня 2019 року «Про затвердження Порядку організації діяльності прокурорів і слідчих органів прокуратури у кримінальному провадженні» керівники прокуратур усіх рівнів, структурних підрозділів прокуратур усіх рівнів, їх перші заступники та заступники відповідно до розподілу обов'язків та у межах повноважень, передбачених КПК України: не рідше одного разу на місяць забезпечують проведення вивчення стану додержання органами прокуратури та іншими правоохоронними органами, крім Національного антикорупційного бюро України, вимог ст. 214 КПК України в частині своєчасності внесення відомостей до ЄРДР, повноти і правильності кваліфікації кримінальних правопорушень за заявами та повідомленнями громадян, матеріалами правоохоронних органів; скасовують незаконні та необгрунтовані постанови слідчих i прокурорів, зокрема про закриття кримінальних проваджень, зупинення досудового розслідування, незалежно від їх оскарження учасниками кримінального провадження та вживають вичерпних заходів реагування щодо осіб, винних у порушенні вимог КПК України чи КK України, наслідком якого стало незаконне притягнення громадян до кримінальної відповідальності чи порушення інтересів держави; організовують щоквартальне проведення перевірок стану та умов зберігання речових доказів, схоронності вилученого та арештованого майна і документів, а також відповідно у визначених законодавством 
випадках вживають невідкладних заходів щодо передачі активів Національному агентству України з питань виявлення, розшуку та управління активами, одержаними від корупційних та інших злочинів [9]; реалізують інші повноваження, передбачені КПК України та зазначеним наказом Генерального прокурора.

Крім того, до адміністративно-правових засобів забезпечення реалізації функції організації і процесуального керівництва досудовим розслідуванням слід зарахувати Наказ Генеральної прокуратури України № 4/1 гн від 3 грудня 2012 р. «Про організацію прокурорського нагляду за додержанням законів органами, які проводять оперативно-розшукову діяльність» [11], а також спільний наказ Генеральної прокуратури України, МВС України, Служби безпеки України, Адміністрації державної прикордонної служби України, Міністерства фінансів України та Міністерства юстиції України № $114 / 1042 / 516 / 1199 / 936 / 1687 / 5$ від 16.11.2012 р. «Про затвердження Інструкції про організацію проведення негласних слідчих (розшукових) дій та використання їх результатів у кримінальному провадженні» [12].

Адміністративно-правове забезпечення реалізації функції прокуратури України щодо представництва в суді законних інтересів держави на теперішній час здійснюється на підставі наказу Генерального прокурора № 389 від 21 серпня 2020 р. «Про організацію діяльності прокурорів щодо представництва інтересів держави в суді» [13].

Відповідно до п. 8 зазначеного наказу керівництву прокуратур усіх рівнів необхідно в межах компетенції забезпечувати своєчасне реагування на судові рішення, що підлягають та потребують оскарження в цивільних, господарських, адміністративних справах, та якісну підготовку апеляційних, касаційних скарг, заяв про перегляд судових рішень за нововиявленими або виключними обставинами, з метою забезпечення реагування на судові рішення, що зачіпають інтереси держави та постановлені без участі прокурора, вступу у справу або подання позову (заяви) постійно здійснювати моніторинг рішень, розміщених в Єдиному державному реєстрі судових рішень, а також отриманої від органів державної влади, органів місцевого самоврядування, інших суб'єктів владних повноважень інформації з цього питання підрозділам представництва в суді та іншим підрозділам регіональних (обласних) прокуратур відповідно до їхньої компетенції здійснювати виявлення судових рішень, які потребують перегляду, шляхом моніторингу постановлених місцевими господарськими та адміністративними судами, апеляційними судами рішень. Апеляційні скарги на судові рішення, якими вирішено спір по суті позовних вимог, необхідно подавати керівникам, першим заступникам, заступникам керівників регіональних (обласних) прокуратур за місцем розташування суду, що розглядав справу, у тому числі у справах за позовами місцевих (окружних) прокурорів та за позовами інших осіб, в які прокурором здійснено вступ [13].

Відповідно до п. 11.2. наказу Генеральної прокуратури України № 389 від 21 серпня 2020 р. «Про організацію діяльності прокурорів щодо представництва інтересів держави в суді» підрозділам представництва в суді та іншим підрозділам регіональних (обласних) прокуратур відповідно до їхньоі компетенції необхідно забезпечувати участь у розгляді справ у місцевих господарських та адміністративних, апеляційних судах за їх місцезнаходженням, місцевих загальних судах у справах за власними позовами (заявами).

У разі встановлення відомостей про вчинення суддею місцевого чи апеляційного суду дисциплінарного проступку керівникам регіональних (обласних) прокуратур у межах визначених законом строків 
застосування дисциплінарного стягнення необхідно ініціювати питання про притягнення судді до відповідальності шляхом звернення у встановленому законом порядку до Вищої ради правосуддя (п. 15.1 вищезазначеного наказу) [13].

Отже, організація представництва органів прокуратури та іï посадових осіб у судах у цивільних, господарських, адміністративних справах у регіональних (обласних) прокуратурах покладена на підрозділи представництва в суді, які безпосередньо здійснюють реалізацію відповідної функції прокуратури.

Функцію нагляду за додержанням законів у процесі виконання судових рішень у кримінальних справах, застосування інших заходів примусового характеру, пов'язаних з обмеженням особистої свободи громадян, органи прокуратури виконують до набрання чинності законом про створення подвійної системи регулярних пенітенціарних інспекцій (п. 9 Розділу XV «Перехідні положення» Конституції України). Створення подвійної системи регулярних пенітенціарних інспекцій на теперішній час не відбулося, тому адміністративно-правове забезпечення реалізації вказаної функції $є$ актуальним напрямом нормотворчої діяльності Офісу Генерального прокурора та керівників регіональних прокуратур. Нині реалізація цієї функції регламентована наказом Генерального прокурора № 353 від 03.08.2020 р. «Про організацію діяльності прокурорів із нагляду за додержанням законів при виконанні судових рішень у кримінальних справах, а також при застосуванні інших заходів примусового характеру, пов'язаних з обмеженням особистої свободи громадян» [14].

Так, відповідно до п. 2 зазначеного наказу, основними завданнями діяльності на цьому напрямі $€$ забезпечення нагляду за додержанням: прав і свобод людини, загальних інтересів суспільства і держави у процесі виконання покарань та інших заходів примусового характеру, пов'язаних 3 обмеженням особистої свободи, а також пробації відповідно до законів України, міжнародних договорів, згода на обов'язковість яких надана Верховною Радою України; законодавства щодо запобігання катуванням чи нелюдському або такому, що принижує гідність, поводженню iз затриманими, взятими під варту та засудженими чи їх покаранню; визначених законодавством вимог режиму, порядку та умов тримання затриманих осіб, а також осіб, до яких застосовано запобіжні заходи у вигляді тримання під вартою, поміщення до психіатричного закладу в умовах, що виключають їхню небезпечну поведінку; визначених законодавством вимог режиму, порядку та умов тримання, а також відбування покарань засудженими; законодавства у процесі виконання покарань, не пов'язаних із позбавленням волі, та пробації; законодавства під час здійснення оперативно-розшукової діяльності оперативними підрозділами органів і установ виконання покарань та слідчих ізоляторів Державної кримінально-виконавчої служби України; законодавства у процесі застосування заходів впливу за адміністративні правопорушення тощо [14].

Згідно із п. 5.2 наказом Генерального прокурора № 353 від 03.08.2020 р. «Про організацію діяльності прокурорів 3 нагляду за додержанням законів при виконанні судових рішень у кримінальних справах, а також при застосуванні інших заходів примусового характеру, пов'язаних 3 обмеженням особистої свободи громадян» відповідним структурним підрозділам регіональних (обласних) прокуратур необхідно здійснювати нагляд у таких органах та установах обласного (міжрегіонального) значення:

- у слідчих ізоляторах, секторах слідчих ізоляторів установ виконання покарань Державної кримінально-виконавчої служби України, в тому 
числі в процесі взаємодії адміністрацій цих установ та конвойних підрозділів щодо конвоювання (тримання) осіб (у тому числі у спецтранспорті), а також у міжрегіональних комісіях із питань розподілу, направлення та переведення для відбування покарання осіб, засуджених до позбавлення волі;

- в оперативних підрозділах міжрегіональних управлінь, слідчих ізоляторів, установ виконання покарань із функцією слідчого ізолятора Державної кримінально-виконавчої служби України під час проведення ними оперативно-розшукової діяльності;

- у спеціальних закладах із надання психіатричної допомоги та закладах із надання психіатричної допомоги - з питань додержання законності в процесі поміщення, лікування осіб, до яких судом застосовано примусові заходи медичного характеру, та осіб, до яких застосовано запобіжний захід - поміщення до психіатричного закладу, а також у процесі надання психіатричної допомоги в примусовому порядку;

- в інших територіальних органах, установах, закладах у процесі виконання судових рішень у кримінальних справах, справах про адміністративні правопорушення, а також застосування інших заходів примусового характеру, пов'язаних з обмеженням особистої свободи громадян [14].

Таким чином, прокурори регіональних (обласних) прокуратур продовжують виконувати функцію нагляду за додержанням законів у процесі виконання судових рішень у кримінальних справах, а також застосування інших заходів примусового характеру, пов'язаних 3 обмеженням особистої свободи громадян, до узгодження пенітенціарного законодавства Конституцією України.

Висновки. Проведене дослідження особливостей реалізації функцій прокуратури на регіональному рівні дало змогу сформулювати висновок про те, що органи прокуратури на регіональному (обласному) рівні забезпечують реалізацію основних функцій прокуратури відповідно до Конституції, Закону України «Про прокуратуру» та наказів Генерального прокурора, а також здійснюють координацію та контроль виконання функцій прокуратури місцевими прокуратурами. Зокрема, прокурори регіональних (обласних) прокуратур підтримують публічне обвинувачення та здійснюють представництво інтересів держави в апеляційних судах. Крім того, прокурори регіональних (обласних) прокуратур забезпечують участь у судових засіданнях починаючи 3 першої інстанції в господарському та адміністративному процесі, що цілком узгоджується з їхнім функціональним призначенням як прокурорів обласного рівня.

3 огляду на кількість та складність завдань, які поставлені перед регіональними прокуратурами, об'єктивною $€$ необхідність збільшення кількості прокурорів регіональних (обласних) прокуратур, які здійснюють безпосереднє процесуальне керівництво досудовим розслідуванням, представництво інтересів держави в суді та нагляд за додержанням законів у процесі виконання судових рішень у кримінальних справах, а також застосування інших заходів примусового характеру, пов'язаних з обмеженням особистої свободи громадян, із метою забезпечення реалізації принципу незалежності прокурорів та підвищення ефективності іхньої діяльності.

Перспективність подальшого дослідження цієї тематики зумовлена загальними тенденціями щодо реформування всієї системи органів кримінальної юстиції та необхідністю створення відповідної доктринальної основи для успішної реалізації запланованих реформ.

У науковій публікациї досліджуються адміністративно-правові засади та особливості реалізації функцій прокуратури на регіональному рівні. 
Методологія дослідження трунтується на органічному поєднанні філософських, загальнонаукових та спеиіально-юридичних методів дослідження. Серед останніх більшою мірою застосовуються методи юридичної догматики та юридичного моделювання.

Зазначається, що сучасний стан організації та діяльності регіональнuх прокуратур потребуе сутmевого удосконалення, шо зумовлено низьким рівнем довіри громадян до органів прокуратури загалом та об'єктивною потребою реформування прокуратур на рівні областей, створення якісно нової моделі організаціі та діяльності прокуратури з використанням найкращого міннародного досвіду та здобутків доктрини адміністративного права.

Аналізуються актуальні питання реалізації функцій прокуратури на регіональному рівні в контексті рівня їх адміністративно-правового забезпечення. Зазначається, що органи прокуратури на регіональному (обласному) рівні забезпечують реалізацію основних функцій прокуратури відповідно до Конституціi, Закону України «Про прокуратуру» та наказів Генерального прокурора, а також здійснюють координацію та контроль виконання функцій прокуратури місизевими прокуратурами. Зокрема, прокурори регіональних (обласних) прокуратур підтримують публічне обвинувачення та здійснюють представниитво інтересів держави в апеляційних судах. Крім того, прокурори регіональних (обласних) прокуратур забезпечують участь у судових засіданнях починаючи 3 першої інстанцї в господарському та адміністративному процесі, шо цүілком узгоджується з їх функціональним призначенням як прокурорів обласного рівня.

Підкреслюеться необхідність збільшення кількості прокурорів регіональних (обласних) прокура- тур, які здійснюють безпосередне процесуальне керівництво досудовим розслідуванням, представниитвво інтересів держави в суді та нагляд за додержанням законів у процесі виконання судових рішень у кримінальних справах, а також застосування інших заходів примусового характеру, пов'язаних з обмеженням особистої свободи громадян, із метою забезпечення реалізації принцииу незалежності прокурорів та підвищення ефективності ї діяльності.

Формулюеться висновок щодо перспективності окремого доктринального дослідження изіё тематики, враховуючи загальні тендениіі щзодо реформування всієї системи органів кримінальної юстиції.

Ключові слова: прокуратура, функції, адміністративно-правові засади, регіональний рівень, законні вимоги, вказівки, представництво, процесуальне керівництво, публічне обвинувачення, нагляд, накази, документообіг.

Mazuryk R. Features of the implementation of the functions of the prosecutor's office at the regional level: administrative and legal aspect

The scientific publication is devoted to the features of the implementation of the functions of the prosecutor's office at the regional level and their administrative and legal support.

The research methodology is based on an organic combination of philosophical, general scientific and special legal research methods. Among the latter, the method of legal dogma and method of legal modeling are used to a greater extent.

It is noted that the current state of organization and activity of regional prosecutor's offices needs significant improvement due to the low level of public confidence in the prosecutor's office as a whole and the objective need to reform prosecutor's offices at the oblast level, create a qualitatively 
new model of organization and activity of the prosecutor's office. achievements of the doctrine of administrative law.

Current issues of implementation of the functions of the prosecutor's office at the regional level in the context of the level of their administrative and legal support are analyzed.

It is noted that the prosecutor's office at the regional (oblast) level ensures the implementation of the main functions of the prosecutor's office in accordance with the Constitution, the Law of Ukraine "On the Prosecutor's Office" and orders of the Prosecutor General, and coordinates and monitors local prosecutor's offices. In particular, regional (oblast) prosecutor's offices provide public prosecution and representation of state interests in courts of appeal. In addition, prosecutors of regional (oblast) prosecutor's offices ensure participation in court hearings from the first instance in the economic and administrative process, which is fully consistent with their functional appointment as prosecutors at the oblast level.

Emphasis is placed on the need to increase the number of prosecutors of regional (oblast) prosecutor's offices who directly supervise pretrial investigations, represent the state in court and monitor compliance with the law in the execution of court decisions in criminal cases, as well as other coercive measures related to restriction of personal freedom of citizens, in order to ensure the implementation of the principle of independence of prosecutors and increase the efficiency of their activities.

The conclusion on the prospects of a separate doctrinal study of this topic is formulated, taking into account the general trends in the reform of the entire system of criminal justice.

Key words: prosecutor's office, functions, administrative and legal principles, regional level, legal require- ments, instructions, representation, procedural management, public prosecution, supervision, orders, document circulation.

\section{Література}

1. Чаплинська Ю.А. Адміністративно-правове забезпечення реформування органів прокуратури Украӥни : автореф. дис. ... докт. юрид. наук : 12.00 .07 «Адміністративне право $і$ процес; фінансове право; інформаиійне право» / Міністерство внутрішніх справ України. Харківський наиіональний університет внутрішніх справ. Харків, 2018. 42 с.

2. Шаганенко П. Адміністративно-правове регулювання організаційного забезпечення діяльності органів прокураmypu. Visegrad Journal on Human Rights. 2015. № 5/1. C. 138-143.

3. Циганок С. Поняття $i$ зміст адміністративно-правового забезпечення діяльності прокуратури України. Підприємництво, господарство і право. 2018. № 11. C. 135-139.

4. Баганець О.О. Адміністративно-правове забезпечення реформи органів прокуратури України : автореф. дис. ... канд. юрид. наук : 12.00 .07 «Адміністративне право і процес; фінансове право; інформаційне право» / ПрАТ «Вищий навчальний заклад «Міжрегіональна академія управління персоналом». Київ, 2019. 16 c.

5. Карпунцов В.В. Процесуальна компетенція органів прокуратури України: адміністративно-nравовий аспект : автореф. дис. ... докт. юрид. наук : 12.00.07 «Адміністративне право i процес; фінансове право; інформаційне право» / Державний науково-дослідний інститут Міністерства внутрішніх справ України. Киї, 2018. 36 с.

6. Про внесення змін до деяких законодавчих актів України щодо першочергових заходів із реформи органів прокуратури : Закон України від 19 вересня 2019 р. № 113-IX. Дата оновлення: 17.10.2019 p. URL: https://zakon.rada. gov.ua/laws / main / 113-IX

7. Конституиія України від 28.06.1996 р. Дата оновлення:01.01.2020 p. URL: https: / / wwr.president.gov.ua/ ua / documents / constitution / konstituciyaukrayini-rozdil-viii

8. Про прокуратуру : Закон України від 14 жовтня 2014 р. № 1697-VII. Дата 
оновлення: 28.11.2019. URL: https:// zakon.rada.gov.ua/laws / show / 1697-18

9. Про затвердження Порядку організації діяльності прокурорів $і$ слідчих органів прокуратури у кримінальному провадженні : Наказ Генеральної прокуратури № 51 від 28 березня 2019 р. URL: https: / / www.gp.gov.ua/ua/gl.html? $m=$ publications\&_t $t=$ rec\&id $=94102$

10. Кримінальний процесуальний кодекс України від 13.04.2012 р. № 4651-VI. Дата оновлення: 15.11.2019. URL: https:// zakon.rada.gov.ua / laws / show / 4651-17

11. Про організацію прокурорського нагляду за додержанням законів орга нами, які проводять оперативно-розшукову діяльність : Наказ Генеральної прокуратури України № 4/1гн від 3 грудня 2012 p. URL: https: / / ww.gp.gov.ua / ua / gl.html?_m=publications\&_t=rec\&id=94102

12. Про затвердження Інструкції про організацію проведення негласних слідчих (розшукових) дій та використання ї результатів у кримінальному провадженні : Наказ Генеральної прокуратури України, МВС України, СБУ, Адміністрациї державної прикордонної служби України, Міністерства фінансів України, Міністерства юстицї України № 114/1042/516/1199/936/1687/5 від 16.11.2012 p. URL: https://zakon.rada. gov.ua/laws / show / v0114900-12

13. Про організацію діяльності прокурорів щодо представниитва інтересів держави в суді : Наказ Генерального прокуратура № 389 від 21 серпня 2020 p. URL: https: / /old.gp.gov.ua/ua/ gl.html?_m=publications\&_t=rec\&id=94102

14. Про організацію діяльності прокурорів з нагляду за додержанням законів при виконанні судових рішень у кримінальних справах, а також при застосуванні інших заходів примусового характеру, пов'язаних з обмеженням особистоі свободи громадян : Наказ Генерального прокурора № 353 від 03.08.202 p0. URL: https: / / zakon.rada.gov.ua / laws / show / v0353905-20\#Text. 